\title{
ASPEK FINANSIAL
}

\section{MATA KULIAH STUDI KELAYAKAN BISNIS}

DOSEN PENGAMPUH SUPRIADI HAMID, S.E.I, M.E.I.

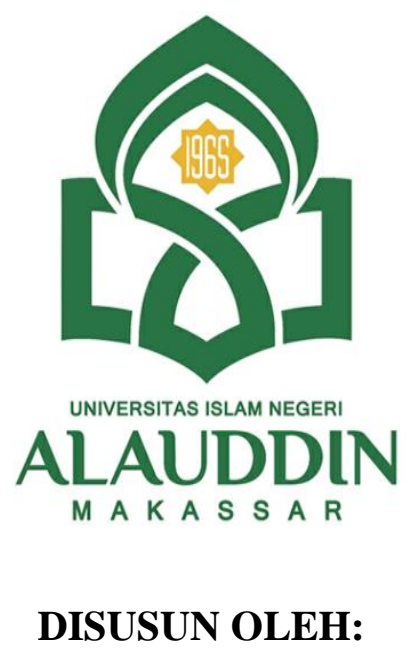

1. Hasriany Huzain (90500120116)

2. Anggraeni Dwi Saputri (90500120108)

3. A. Syahrul Ramadhan Rasyid (90500120112)

4. Muhammad Mufthih Tsani (90500120128)

\author{
PRODI PERBANKAN SYARIAH
}

FAKULTAS EKONOMI DAN BISNIS ISLAM

UIN ALAUDDIN MAKASSAR

2021/2022 


\section{KATA PENGANTAR}

Alhamdulillahirobbil'alamiin, puji syukur kita panjatkan kehadirat Allah SWT, yang telah senantiasa melimpahkan rahmat, taufik, dan hidayahNya, sehingga penulisan makalah ini dapat terselesaikan. Sholawat serta salam semoga tetep tercurah limpahkan kepada junjungan kita Nabi Muhammad SAW yang telah membawa kabar gembira bagi umat yang bertaqwa.

Makalah yang berjudul Aspek Finansial disusun dalam rangka memenuhi tugas mata kuliah Studi kelayakan. Dalam penulisan makalah ini, penulis mendapat bantuan dari berbagai pihak. Oleh karena itu, pada kesempatan ini penulis mengucapkan terima kasih kepada Supriadi Hamid, S.E.I, M.E.I. Selaku Dosen pengampu mata kuliah Studi Kelayakan Bisnis, yang selalu memberikan bimbingan dan motivasi kepada penulis dalam menyusun makalah ini.

Penulis menyadari bahwa dalam penulisan makalah ini masih belum sempurna dan banyak kekurangan. Oleh karena itu, kritik dan saran yang membangun sangat penulis harapkan. Mudah-mudahan makalah ini dapat memberikan manfaat baik untuk kami secara individu, lembaga, maupun pihak lain yang bersangkutan.

Takalar, 24 September 2021

Penulis 


\section{DAFTAR ISI}

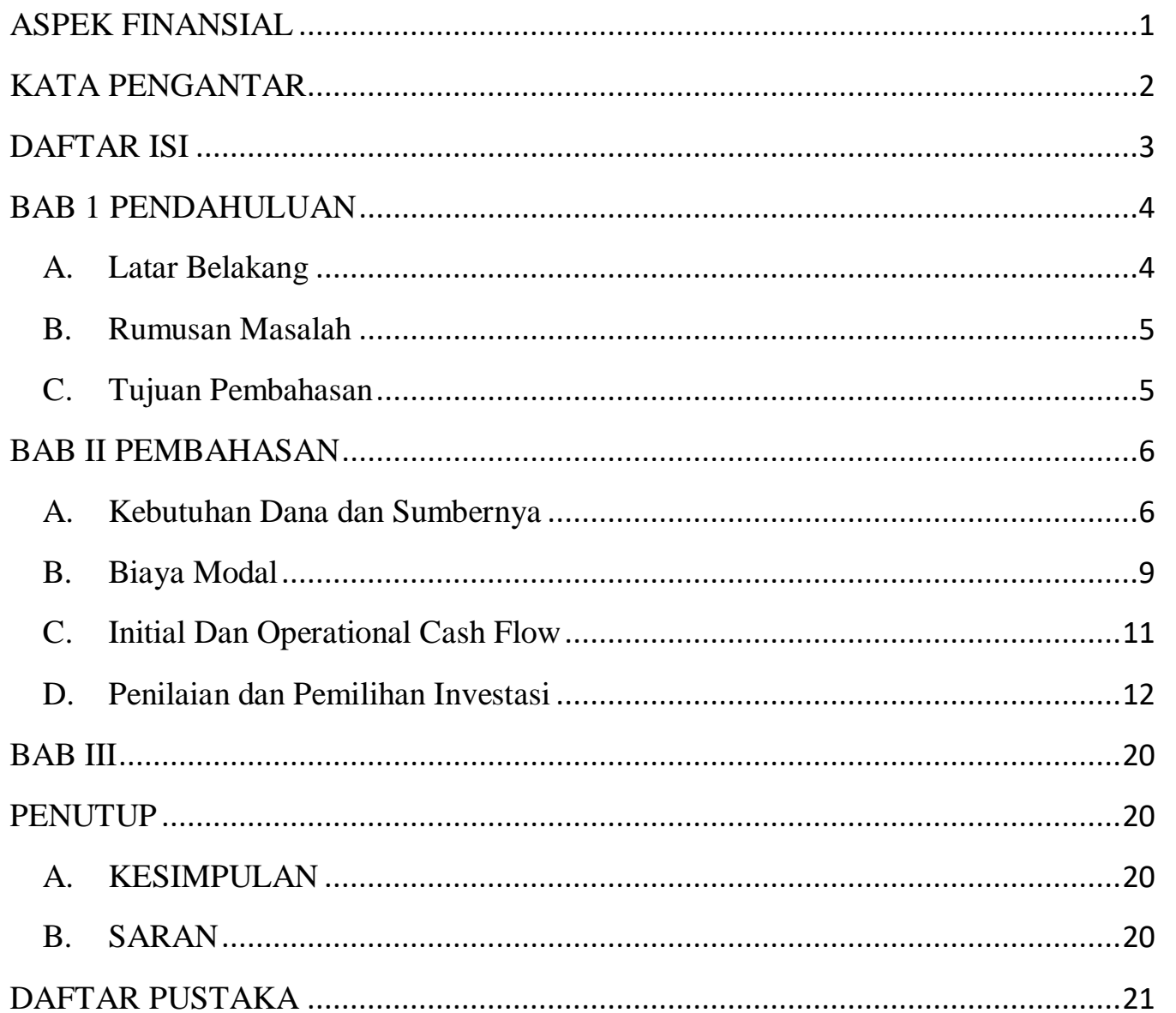




\section{BAB 1}

\section{PENDAHULUAN}

\section{A. Latar Belakang}

Studi kelayakan sangat dibutuhkan oleh banyak pihak, terutama investor yang merupakan inisiator, bank sebagai pemberi pinjaman, dan tentunya negara-negara yang memberikan fasilitas hukum dan regulasi dengan kepentingan yang berbeda-beda. Investor tertarik untuk mengetahui tingkat pengembalian investasi, bank tertarik untuk mengetahui jumlah agunan yang diberikan dan kelancaran pengembaliannya, dan pemerintah lebih tertarik pada manfaat investasi berbasis makro ini dalam perekonomian. Distribusi kesempatan kerja, dll.

Mengingat kondisi kerangka masa depan yang tidak pasti, studi kelayakan menyelidiki berbagai aspek dan menyelidiki kelayakan sehingga temuan dapat digunakan untuk menentukan apakah suatu proyek atau bisnis layak. Ditunda atau bahkan dibatalkan. Hal tersebut di atas adalah menunjukan bahwa dalam studi kelayakan akan melibatkan banyak tim dari berbagai ahli yang sesuai dengan bidang atau aspek masing-masing seperti ekonom, hukum, psikolog, akuntan, perekayasa teknologi dan lain sebagainya.

Dan studi kelayakan biasanya berorientasi pada keuntungan, yang berarti penelitian yang berfokus pada arah yang diharapkan perusahaan, yaitu penelitian yang berfokus pada manfaat ekonomi, dan proyek dapat dilakukan dan dilakukan tanpa mempertimbangkan nilai atau manfaat ekonomi. 


\section{B. Rumusan Masalah}

1. Apa yang di maksud aspek keuangan dan sumber-sumber dana?

2. Apa yang di maksud aliran kas?

3. Apa yang di maksud biaya modal?

4. Apa yang di maksud initial dan operational cash flow?

5. Apa yang di maksud penilaian dan pemilihan investasi?

6. Bagaimana contoh laporan keuangan dan perencanaan keuangan?

\section{Tujuan Pembahasan}

1. Untuk mengetahui aspek keuangan dan sumber-sumber dana.

2. Untuk mengetahui aliran kas.

3. Untuk mengetahui biaya modal.

4. Untuk mengetahui initial dan operational cash flow.

5. Untuk mengetahui penilaian dan pemilihan investasi.

6. Untuk mengetahui bagaimana contoh laporan keuangan dan perencanaan keuangan. 


\section{BAB II \\ PEMBAHASAN}

\section{A. Kebutuhan Dana dan Sumbernya}

Keuangan adalah salah satu fungsi bisnis yang bertujuan untuk membuat keputusan investasi, keuangan, dan dividen. Keputusan investasi bertujuan untuk menetapkan pedoman terkait dengan:

a) Kebijakan pengalokasian sumber dana secara optimal

b) Kebijakan modal kerja

c) Kebijakan investasi yang berdampak pada strategi perusahaannya lebih luas (merger dan akuisisi)

Keputusan pembiayaan fokus pada mendapatkan deal terbaik untuk mendapatkan dana tambahan atau dana untuk mendukung kebijakan investasi. Sumber dana dapat dibagi menjadi dua kategori yaitu:

1. Internal

2. Sumber eksternal yaitu:

a) Dalam bentuk utang yang meliputi penundaan pembayaran utang, pinjaman jangka pendek sebagai tambahan modal kerja, dan pinjaman jangka panjang (obligasi) sebagai dana investasi.

b) Menerbitkan saham, baik dalam bentuk saham perdana (initial public offer/IPO) maupun saham biasa baru sebagai sumber modal investasi dalam rangka ekspansi perusahaan. 


\section{Kebutuhan Dana}

Kebutuhan dana adalah semua dana yang dibutuhkan untuk memproduksi barang, memasarkan barang dan kebutuhan lainnya seperti transportasi. Dan studi kelayakan biasanya digolongkan menjadi dua bagian yang berdasarkan pada orientasi yang diharapkan oleh suatu perusahaan yaitu berdasarkan orientasi laba, yang dimaksud adalah studi yang menitik-beratkan pada keuntungan yang secara ekonomis, dan orientasi tidak pada laba (social), yang dimaksud adalah studi yang menitik-beratkan suatu proyek tersebut bisa dijalankan dan dilaksanakan tanpa memikirkan nilai atau keuntungan ekonomis. ${ }^{1}$

Aspek keuangan ini juga menjelaskan bagaimana memperkirakan kebutuhan sumber daya untuk aset tetap dan modal kerja. Dari sudut pandang keuangan atau keuangan, sebuah proyek dianggap layak jika dapat menghasilkan keuntungan dan memenuhi kewajiban keuangannya.

Dalam pembahasan studi kelayakan ini aspek keuangan adalah merupakan suatu aspek yang sangat menentukan berjalannya invetasi yang akan dilakukan. Karena aspek keuangan dapat menentukan rencana investasi melalui perhitungan biaya dan manfaat yang diharapkan, dengan cara membandingkan antara pengeluaran dan pendapatan, seperti ketersediaan dana, biaya modal, kemampuan untuk membayar kembali investasi yang telah dilakukan dalam waktu yang

\footnotetext{
${ }^{1}$ Kasmir dan Jakfar. Studi Kelayakan Bisnis. Edisi Kedua. Jakarta: Kencana Prenada Media Group, 2008.
} 
telah ditentukan, serta dapat menilai apakah investasi tersebut berjalan sesuai dengan yang diharapkan.

Aspek keuangan juga dapat dikatakan sebagai dasar terlaksana atau tidaknya suatu investasi yang diinginkan. Maka dari itu dalam menilai investasi harus benar-benar memperhatikan dana yang tersedia apakah dapat digunakan secara maksimal demi mencapai tujuan dari perusahaan. ${ }^{2}$

Suatu aktivitas bisnis tidak akan dapat berjalan dengan baik bila tidak didukung oleh ketersediaan dana yang baik dan mencukupi. Prakiraan yang baik diperlukan untuk menentukan jumlah uang yang dibutuhkan untuk menjalankan bisnis. Prakiraan atau perkiraan ini akan bervariasi menurut jenis proyek. Secara umum perkiraan dana yang dibutuhkan tergantung dari kompleksitas kegiatan pendanaan itu sendiri.

a. Alokasi Dana untuk Aktiva Tetap

Aktiva tetap terdiri dari aktiva tetap berwujud, dan aktiva tetap tidak berwujud .

b. Alokasi Dana untuk Modal kerja

Secara umum modal kerja dapat diartikan dalam dua bentuk, yaitu: (a) gross working capital dan (b) net working capital.

2. Sumber Dana

Jumlah uang yang relatif besar biasanya diperlukan untuk mendanai kegiatan investasi. Dana dapat dikumpulkan dari berbagai sumber, termasuk ekuitas, utang, atau keduanya. Keputusan untuk menggunakan ekuitas dan/atau modal pinjaman tergantung pada jumlah modal yang diperlukan atas kebijaksanaan pengusaha. Pertimbangan tersebut tidak lain adalah kekuatan dan kelemahan penggunaan salah satu modal, atau kombinasi modal. Dilihat dari

\footnotetext{
${ }^{2}$ Umar, Husein, "Studi Kelayakan Bisnis, Teknik Menganalisis Kelayakan Usaha Secara Komperhensif”, PT. Gramedia Pustaka Utama, 2005.
} 
segi sumber asalnya, modal dibagi 2 (dua) macam, yaitu:

1. Modal Asing (modal pinjaman)

Modal asing atau modal pinjaman merupakan modal yang diperoleh dari pihak luar perusahaan dan biasanya diperoleh secara pinjaman. Sumber dana dari modal asing dapat siperoleh antara lain:

a) Pinjaman dari dunia perbankan

b) Pinjaman darilembaga keuangan seperti perusahaan modal ventura, asuransi, leasing, dana pension, atau lembaga keuangan lainnya.

c) Pinjaman dari perusahaan nonbank.

\section{Modal Sendiri}

Modal sendiri adalah modal yang diperoleh dari pemilik perusahaan dengan cara mengeluarkan saham baik tertutup atau terbubuka. Perolehan dana dari modal sendiri biasanya berasal dari:

a) Setoran dari pemegang saham.

b) Dari cadangan laba.

c) Atau dari laba yang belum dibagi. ${ }^{3}$

\section{B. Biaya Modal}

Faktor-faktor yang termasuk dalam biaya investasi biasanya disesuaikan dengan jenis perusahaan yang Anda operasikan. Secara umum biaya kebutuhan investasi meliputi:

1) Biaya pra investasi

2) Biaya akhir tetap

\footnotetext{
${ }^{3}$ Tanjung, Baharuddin Nur. Pedoman Penulisan Karya Ilmiah (Proposal, Skripsi, dan Tesis).
} Medan: Kencana Prenada Media Group, 2005. 
3) Biaya operasi

Secara umum komponen biaya kebutuhan investasi adalah sebagai berikut:

1. Biaya pra investasi terdiri dari:

a) Biaya pembuatan study

b) Biaya pengurusan izin-izin

2. Biaya pembelian aktiva tetap seperti:

A. Aktiva tetap berwujud antara lain:

- Tanah

- Mesin-mesin

- Bangunan

- Peralatan

- Inventaris kantor

- Aktiva berwujud lainnya

B. Aktiva tetap tidak berwujud antara lain:

- Good will

- Hak cipta

- Lisensi

- Merk pedagang

3. Biaya operasional yang terdiri dari:

- Upah dan gaji karyawan

- Biaya listrik

- Biaya telpon dan air

- Biaya pemeliharaan

- Pajak

- Premi asuransi 
- Biaya pemasaran ${ }^{4}$

\section{Initial Dan Operational Cash Flow}

Cash flow merupakan aliran kas dari suatu usaha yang terdiri dari penerimaan usaha (inflow) dan pengeluaran usaha (outflow). Menurut Kasmir dan Jakfar (2007:95), cashflow adalah jumlah uang yang masuk dan keluar dalam suatu perusahaan mulai dari investasi dilakukan sampai dengan berakhirnya investasi tersebut. Aliran kas disusun untuk menunjukan perubahan kas selama satu periode tertentu serta memberikan alasan mengenai perubahan kas tersebut dengan menunjukkan dari mana sumber-sumber kas dan penggunaanpenggunaannya.

Arus kas adalah jumlah uang yang masuk dan keluar dari perusahaan sejak investasi dilakukan hingga akhir investasi. Dalam hal ini, investor yang paling penting adalah jumlah kas bersih yang mengalir ke perusahaan dari dana yang diinvestasikan. Pentingnya kas utama bagi investor dibandingkan dengan keuntungan perusahaan diberikan sebagai berikut:

1. Kas diperlukan untuk memenuhi kebutuhan uang tunai sehari-hari.

2. Kas digunakan untuk membayar semua kewajiban yang jatuh tempo.

3. Kas juga digunakan untuk melakukan investasi kembali.

4. Jenis-jenis cash flow yang dikaitkan dengan suatu usaha terdiri dari:

a. Intial cash flow

b. Operasional cash flow

4 Journal.uny.ac.id/index.php/cp/articleviewFile/383/pdf diakses pada 24 September 2021 pukul 08.33 WIB. 
c. Terminal cash flow

Initial Cash Flow : Aliran kas yang berhubungan dengan pengeluaran" kas untuk keperluan investasi, atau seluruh pengeluaran kas untuk pengadaan aset" tetap. Kebutuhan dana yang akan di gunakan untuk modal kerja juga termasuk dalam Initial Cash Flow.

Operation Cash Flow : Aliran kas yang akan di gunakan untuk menutup investasi, Operation cash flow di terima setiap tahun selama umur investasidalam bentuk aliran kas bersih. Operation cash flow inilah yang sering disebut juga cash flow saja. Operation cash flow dihitung dengan menambahkan laba bersih dan non cash cost.

Terminal Cash Flow : Aliran kas yang diterima sebagai akibat habisnya umur ekonomis suatu proyek investasi. Biasanya setelah suatu proyek investasi habis umur ekonomisnya masih ada penerimaan kas, yang berasal dari penjualan aset tetap dan sisa dana modal kerja. ${ }^{5}$

\section{Penilaian dan Pemilihan Investasi}

Adapun kriteria penilaian yang biasa digunakan untuk menuntukan kelayakan suatu usaha atau investasi adalah:

1. Playback period (PP)

2. Average rate of return (ARR)

3. Net present value (NPV)

4. Internal rate of return (IRR)

5. Profitability index (IP)

\footnotetext{
${ }^{5}$ Nasarudin, Indo Yama, "Analisis Kelayakan Ekonomi Dan Finansial Usaha Ikan Lele Asap Di Wilayah Pekanbaru”, Jurnal Etikonomi Volume 11 No.2, 2012.
} 
6. Serta berbagai rasio keuangan seperti rasio likuiditas, solvabilitas, aktivitas dan profabilitas. ${ }^{6}$

Investasi dapat diukur dengan berbagai metode, diantaranya yaitu menggunakan metode Net Present Value, Internal Rate of Return, Benefit/Cost Ratio, Payback Period, Profitability Index, dan Break Even Point.

1) Net Present Value (NPV)

Net Present Value yaitu selisih antara Present value dari investasi dengan nilai sekarang dari penerimaan-penerimaan kas bersih (aliran kas operasional maupun aliran kas terminal) di masa yang akan datang. Untuk menghitung nilai sekarang perlu ditentukan tingkat bunga yang relevan.

2) Internal Rate of Return (IRR)

Internal Rate of Return merupakan metode yang digunakan untuk mencari tingkat bunga yang menyamakan nilai sekarang dari arus kas yang diharapkan di masa yang akan datang atau penerimaan kas, dengan mengeluarkan investasi awal.

Internal Rate of Return dapat diidentifikasi sebagai tingkat bunga yang akan menjadikan jumlah nilai sekarang dari proceed yang diharapkan akan diterima sama dengan jumlah nilai sekarang dari pengeluaran modal. Pada dasarnya IRR harus dicari dengan cara trial and error.

3) Benefit/Cost Ratio (B/C Ratio)

$B / C$ Ratio merupakan metode yang dilakukan untuk melihat beberapa manfaat yang diterima oleh proyek untuk satu rupiah pengeluaran proyek. Net B/C Ratio adalah suatu rasio yang membandingkan antara

\footnotetext{
${ }^{6}$ ejurnal.unisri.ac.id/index.php/widyawacana/article/viewFile/420/377 diakses pada 24 September 2021. pukul 08.30 WIB.
} 
benefit atau penerimaan dari suatu usaha dengan biaya yang dikeluarkan untuk merealisasikan rencana pendirian dan pengoperasian usaha tersebut.

4) Payback Period (PP)

Payback Period adalah suatu periode yang diperlukan untuk menutup kembali pengeluaran investasi (Initial Cash Investment) dengan menggunakan aliran kas, dengan kata lain , $P P$ merupakan rasio antara Initial Cash Investment dengan aliran kas masuknya yang hasilnya merupakan satuan waktu. Selanjutnya nilai rasio ini dibandingkan dengan maksimum payback period yang dapat diterima.

5) Profitability Index (PI)

Profitability Index merupakan cara lain lagi untuk mengukur profitibilitas rencana investasi proyek. Dalam metode ini, profitibilitas dicari dengan jalan memperbandingkan jumlah seluruh present value net cash flows dan salvage value dengan nilai investasi proyek. Dengan kata lain, Profitability Index merupakan perbandingan antara nilai cash flow investasi dengan biaya investasi yang dikeluarkan.

6) Break Even Point (BEP)

BEP merupakan suatu keadaan atau penjualan usaha dimana jumlah manfaat (pendapatan) sama besarnya dengan pengeluaran (biaya) dengan kata lain keadaan dimana perusahaan tidak mendapatkan keuntungan dan tidak menderita kerugian ${ }^{7}$

\footnotetext{
${ }^{7}$ Rangkuti, Freedy, "Business Plan, Teknik Membuat Perencanaan Bisnis dan Analisis Kasus", PT. Gramedia Pustaka Utama, 2006.
} 
A. Perencanaan Keuangan

Perencanaan keuangan merupakan salah satu bagian dari proses perencanaan organisasi (corporate planning). Dari perencanaan diharapkan perusahaan dapat menghindari kesalahan-kesalahan dan mengusahakan untuk menghasilkan keputusan yang terbaik yang pada akhirnya mampu meningkatkan kinerja dari suatu perusahaan. Perencanaan keuangan perlu menilai kondisi dan kondisi keuangan masa depan. Oleh karena itu, dimungkinkan untuk memperkirakan apakah keadaan perusahaan perlu menambah dana eksternal seperti profitabilitas perusahaan di masa depan.

Perencanaan keuangan memberikan panduan bagi perubahan dan pertumbuhan yang terjadi di dalam perusahaan. Karena tujuan utama dari perencanaan keuangan adalah untuk memberikan arah pertumbuhan dan perkembangan pada perusahaan secara berkelanjutan. Manfaat Perencanaan Keuangan:

1. Mengetahui interaksi yakni rencana keuangan harus dapat menunjukkan hubungan antara rencana investasi dan pendanaan.

2. Menilai berbagai pilihan atau alternatif.

3. Menghindari kejutan.

4. Memastikan kelayakan sasaran.

B. Contoh Laporan Keuanagn 


\begin{tabular}{|c|c|}
\hline $\begin{array}{c}\text { PT. AMEUIA MERCHANDISE } \\
\text { Laporan Neraca (BS) } \\
\text { Periode } 01 \text { Januari } 2018 \text { s.d } 31 \text { Januari } 2018 \\
\text { Klasinikasi: Semua }\end{array}$ & \\
\hline Akun & 31 Januari 2018 \\
\hline \multicolumn{2}{|l|}{ 1.0.00-ASET } \\
\hline \multicolumn{2}{|l|}{ 1.1.00 - ASET LANCAR } \\
\hline 1.1.01 - Kas & $800.224 .338,54$ \\
\hline 1.1.01.01 - Kas besar & 554.904 .337 .64 \\
\hline 1.1.01.02 - Petty Cash & 245.320 .000 .90 \\
\hline 1.1.02 - Bank & $463.165 .395,19$ \\
\hline 1.1.02.01 - Bank BCA & 209.034 .840 .00 \\
\hline 1.1.02.02 - Bank USD & 87.165 .185 .20 \\
\hline 1.1.02.04 - Mandiri IDR & 57.214 .600 .00 \\
\hline $1.1 .02 .05-8 \mathrm{NI}$ & 639.000 .00 \\
\hline 1.1.02.06-Bank BCA Yen & $1.204 .400,00$ \\
\hline 1.1 .02 .07 - CIMB USD & 110.224 .369 .99 \\
\hline 1.1.02.08 - Bank HSBC & $(2.400 .000 .00)$ \\
\hline 1.1.02.09 - kas besar & $83.000,00$ \\
\hline 1.1.03 - Piutang & $1.279 .209 .150,00$ \\
\hline 1.1.01.03 - Deposit Tiket & 10.000 .000 .00 \\
\hline 1.1.03.01 . Piutang Usaha & 1.264.419.150.00 \\
\hline 1.1.03.03 - Piutang Karyawan & 4.790 .000 .00 \\
\hline 1.2.05-Persediaan & $670.327 .992,31$ \\
\hline 1.1.05.01 - Persediaan Barang Dagang & $670.327 .992,31$ \\
\hline 1.1.06-Perlengkapan & $1.150 .000,00$ \\
\hline 1.1.06.01 - Perlengkapan Kantor & 1.150 .000 .00 \\
\hline 1.1.07 - Pajak Dibayar Dimuka & $21.849 .919,00$ \\
\hline 1.1.07.01 - Pajak PPN Masukan & $18.698 .719,00$ \\
\hline 1.1.07.04 - Pajak Dibayar Dimuka PPh 23 & 3.151 .200 .00 \\
\hline 1.1.08 - Biaya Dibayar Dimuka & $(94.160 .000,00)$ \\
\hline 1.1.08.02 - Uang Muka/Pinjaman Kepada Karyawan & $(5.950 .000,00)$ \\
\hline 1.1.08.03 - Vang Muka Pembelian & $(88.010 .000 .00)$ \\
\hline 1.1.08.04 - Cash Advance & $(200.000,00)$ \\
\hline \multirow{2}{*}{\multicolumn{2}{|c|}{ 1.2.00 - ASET TIDAK-LANCAR }} \\
\hline & \\
\hline 1.2.01-Aset Tetap & $995.278 .604,05$ \\
\hline 1.2.01.02 - Bangunan & $1.000 .000 .0003 \triangleq$ \\
\hline 1.2.01.03 - Kendaraan & $105.550 .000, \overline{3}=$ \\
\hline 1.2.01.05 - Peralatan Kantor & 16.779 .000 .00 \\
\hline 1.2.01.07 - Akumulasi Penyusutan Bangunan & $(36.492 .872 .81)$ \\
\hline 1.2.01.08 - Akumulasi Penyusutan Kendaraan & $(55.760 .416 .66)$ \\
\hline 1.2.01.10 - Akumulasi Penyusutan Peralatan Kantor & $(34.797 .106 .48)$ \\
\hline 1.2.04 - KITCHEN MACHINERY & $100.000,00$ \\
\hline 1.2.04.01-Freezer & 100.000 .00 \\
\hline TOTAL ASET & $4.137 .145 .399,09$ \\
\hline \multicolumn{2}{|l|}{2.0 .00 - KEWAJIBAN } \\
\hline \multicolumn{2}{|l|}{ 2.1.00- KEWAJIBAN LANCAR } \\
\hline 2.1.01 - Utang & $2.314 .649 .860,00$ \\
\hline 2.1.01.01 - Utang Usaha & $2.314 .649 .860,00$ \\
\hline 2.1.02 - Utang Pajak & $80.381 .640,54$ \\
\hline 2.1.02.01 - Utang PPN Keluaran & 79.449 .954 .54 \\
\hline 2.1.02.02 - Utang PPh 21 & 803.686 .00 \\
\hline 2.1 .02 .04 - Utang PPh 23 & 128.000 .00 \\
\hline 2.1.03 - Biaya Terutang (Masih Marus Dibayar) & $77.352 .000,00$ \\
\hline 2.1.03.01 - Utang Gaj/Upah & $57.570 .000,00$ \\
\hline 2.1.03.03 - Utang BPJS Kesehatan & $(218.000,00)$ \\
\hline 2.1.03.06 - Utang Depodit & 20.000 .000 .00 \\
\hline 2.1.04 - Utang Lainnya & $1.000 .000,00$ \\
\hline 2.1.04.04-Pendapatan Diterima Dimuka & $500.000,00$ \\
\hline 2.1.04.05 - Utang Lainnya & 500.000 , \\
\hline TOTAL KEWAIBAN & $2.473 .383 .500, \ldots$ \\
\hline \multicolumn{2}{|l|}{ 3.0.00 - EKUITAS } \\
\hline \multicolumn{2}{|l|}{3.1 .00 - EKUITAS } \\
\hline 3.1.01-Modal & $394.160 .000,00$ \\
\hline 3.1.01.01-Modal Disetor & 393.460 .000 .00 \\
\hline 3.1.01.02 - Utang Direksi & 700.000 .00 \\
\hline 3.1.02 - Saldo Laba & $1.269 .601 .898,55$ \\
\hline 3.1.02.01 - Saldo Laba Ditahan & 917.297 .687 .14 \\
\hline 3.1.02.02 -Saldo Laba Tahun Berjalan & 352.304 .211 .41 \\
\hline TOTAL EKUITAS & $1.663 .761 .898,55$ \\
\hline
\end{tabular}




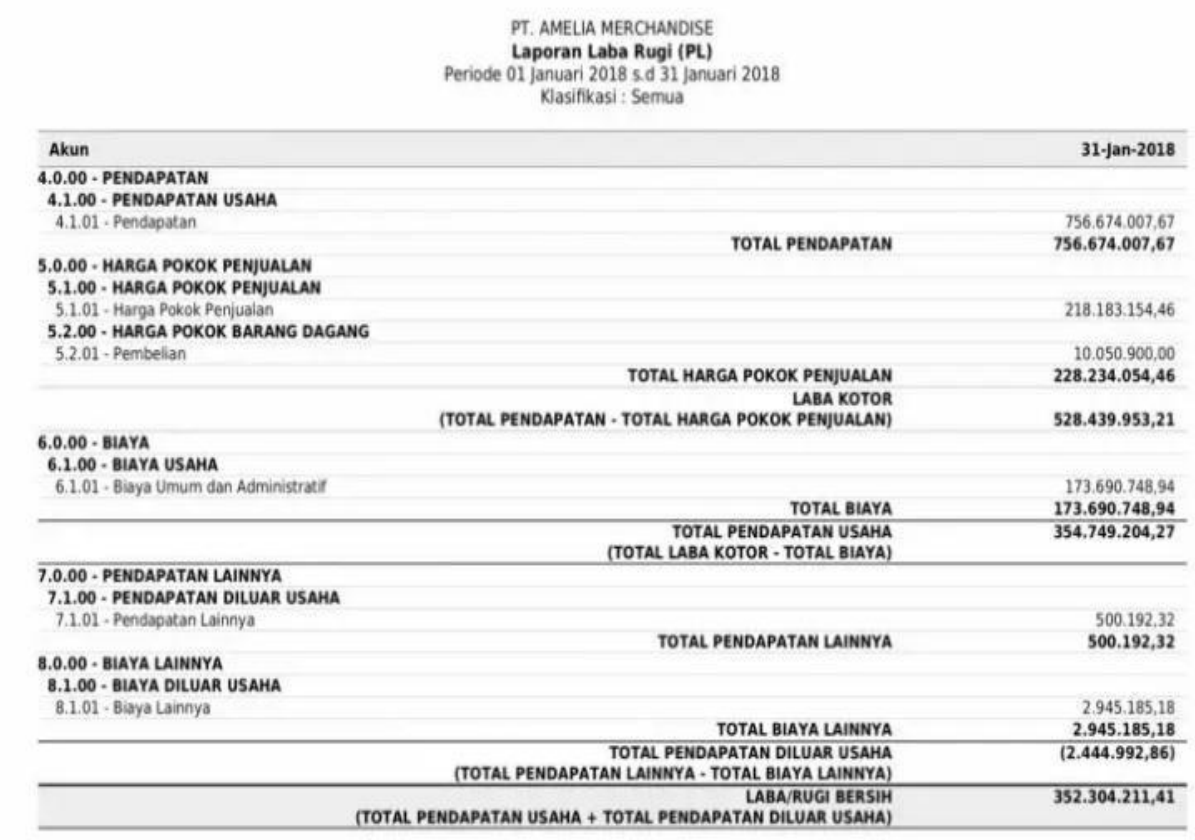


PT. AMEUA MERCHANDISE Laporan Arus Kas

Periode 01 Januari 2018 s.d 31 Januari 2018

Klasifikasi: Semua

\begin{tabular}{|c|c|}
\hline \multicolumn{2}{|l|}{ A. ARUS KAS DARI OPERASIONAL } \\
\hline \multicolumn{2}{|l|}{ Penerimaan Kas dari Pelanggan } \\
\hline 4.1.01.01 - Penjualan & $777.882 .959,58$ \\
\hline 4.1.01.02 - Potongan Penjualan & $(11.650 .951,91)$ \\
\hline 4.1.01.03 - Retur Penjualan & $(9.558 .000,00)$ \\
\hline 1.1.03.01 - Kenaikan Pada Piutang Usaha & $(488.202 .500,00)$ \\
\hline 2.1.02.01 - Kenaikan Pada Utang PPN Keluaran & $9.120 .000,00$ \\
\hline 2.1.04.04 - Kenaikan Pada Pendapatan Diterima Dimuka & $500.000,00$ \\
\hline 1.1.07.04 - Kenaikan Pada Pajak Dibayar Dimuka PPh 23 & $(1.995 .000,00)$ \\
\hline Total Penerimaan Kas dari Pelanggan & $276.096 .507,67$ \\
\hline \multicolumn{2}{|l|}{ Kas yang Dibayarkan ke Vendor } \\
\hline 2.1.01.01 - Kenaikan Pada Utang Usaha & $15.213 .020,00$ \\
\hline 1.1.07.01 - Kenaikan Pada Pajak PPN Masukan & $(225.000,00)$ \\
\hline 5.1.01.01 - Harga Pokok Penjualan & $(218.183 .154,46)$ \\
\hline 5.2.01.01 - Pembelian & $(10.050 .900,00)$ \\
\hline \multicolumn{2}{|l|}{ Total Kas yang Dibayarkan ke Vendor } \\
\hline \multicolumn{2}{|l|}{ Kas yang Dibayarkan untuk Pajak } \\
\hline 1.1.01.01 - Penurunan Pada Kas besar & $235.590 .700,00$ \\
\hline Total Kas yang Dibayarkan untuk Pajak & $235.590 .700,00$ \\
\hline \multicolumn{2}{|l|}{ Kas yang Dibayarkan untuk Beban Pokok Penjualan Operasional } \\
\hline Total Kas yang Dibayarkan untuk Beban Pokok Penjualan Operasional & 0,00 \\
\hline \multicolumn{2}{|l|}{ Kas yang Dibayarkan untuk Biaya Operasional } \\
\hline 6.1.01.01 - Biaya Gaji & $(125.920 .000,00)$ \\
\hline 6.1.01.06 - Biaya Insentif dan Bonus & $(5.000 .000,00)$ \\
\hline 6.1.01.08 - Biaya Makan & $(1.150 .000,00)$ \\
\hline 6.1.01.09 - Biaya Medis & $(200.000,00)$ \\
\hline 6.1.01.10 - Biaya Perjalanan Dinas & $(300.000,00)$ \\
\hline 6.1.01.11 - Biaya Transportasi, BBM, Toll \& Parkir & $(350.000,00)$ \\
\hline 6.1.01.12 - Biaya Listrik & $(12.700 .000,00)$ \\
\hline 6.1.01.13-Biaya Gas & $(200.000,00)$ \\
\hline 6.1.01.16 - Biaya Keamanan dan Kebersihan & $(350.000,00)$ \\
\hline 6.1.01.18 - Biaya ATK \& Fotocopy & $(500.000,00)$ \\
\hline 6.1.01.19 - Biaya Perlengkapan & $(3.970 .353,00)$ \\
\hline 6.1.01.22 - Biaya Servis dan Pemeliharaan & $(160.000,00)$ \\
\hline 6.1.01.24 - Biaya Entertainment dan Representasi & $(1.000 .000 .00)$ \\
\hline 6.1.01.33 - Biaya Operasional Lainnya & $(2.940 .000,00)$ \\
\hline 6.1.01.34 - Biaya Penyusutan Bangunan Kantor & $(5.326 .206,14)$ \\
\hline 6.1.01.35 - Biaya Penyusutan Kendaraan & $(9.406 .250,00)$ \\
\hline 6.1.01.36 - Biaya Penyusutan Peralatan Kantor & $(4.217 .939,80)$ \\
\hline 1.2.01.08 - Kenaikan Pada Akumulasi Penyusutan Kendaraan & 9.406 .250 .00 \\
\hline 1.2.01.10 - Kenaikan Pada Akumulasi Penyusutan Peralatan Kantor & 4.217 .939 .80 \\
\hline Total Kas yang Dibayarkan untuk Biaya Operasional & $(160.066 .559,14)$ \\
\hline \multicolumn{2}{|c|}{ Kas yang Dibayarkan/Diterima Lainnya } \\
\hline 7.1.01.04 - Pendapatan Diluar Usaha Lainnya & 192,32 \\
\hline 7.1.01.02 - Laba Atas Selisih Kurs & $500.000,00$ \\
\hline 8.1.01.03 - Rugi Atas Selisih Kurs & $(2.945 .185,18)$ \\
\hline \multirow{2}{*}{$\begin{array}{r}\text { Total Kas yang Dibayarkan/Diterima Lainnya } \\
\text { TOTAL ARUS KAS DARI OPERASIONAL }\end{array}$} & $(2.444 .992,86)$ \\
\hline & $135.929 .621,21$ \\
\hline \multicolumn{2}{|l|}{ B. ARUS KAS DARI INVESTASI } \\
\hline \multicolumn{2}{|l|}{ Kas dari Investasi } \\
\hline 1.2.01.03 - Kenaikan Pada Kendaraan & $(5.500 .000,00)$ \\
\hline 1.2.01.05 - Kenaikan Pada Peralatan Kantor & $(10.000 .000,00)$ \\
\hline \multirow{2}{*}{$\begin{array}{r}\text { Total Kas dari Investasi } \\
\text { TOTAL ARUS KAS DARI INVESTASI }\end{array}$} & $(15.500 .000,00)$ \\
\hline & $(15.500 .000,00)$ \\
\hline \multicolumn{2}{|l|}{ C. ARUS KAS DARI PENDANAAN } \\
\hline \multicolumn{2}{|l|}{ Kas dari Pendanaan } \\
\hline 3.1.01.01 - Kenaikan Pada Modal Disetor & $100.600 .000,00$ \\
\hline Total Kas dari Pendanaan & $100.600 .000,00$ \\
\hline TOTAL ARUS KAS DARI PENDANAAN & $100.600 .000,00$ \\
\hline KAS PADA SAAT AWAL PERIOD & $1.063 .668 .218,92$ \\
\hline TOTAL KAS YANG DITERIMA & $221.029 .621,21$ \\
\hline KAS PADA SAAT AKHIR PERIOD & $1.284 .697 .840,13$ \\
\hline
\end{tabular}


PT. AMELIA MERCHANDISE

Laporan Perubahan Modal (EQ)

Untuk tahun yang berakhir 31 Januari 2018

Klasifikasi: Semua

Modal (Awal) per 31 Desember 2017

Modal (Tambahan) untuk Tahun yang berakhir 31 Jan 2018

Saldo Laba Ditahan per 31 Des 2017

Saldo Laba Tahun Berjalan untuk Tahun yang berakhir 31 Jan 2018

Dividen untuk Tahun yang berakhir 31 Jan 2018

Saldo Laba Ditahan per 31 Jan 2018

Modal Akhir

293.560.000,00 $100.600 .000,00$

917.297 .687 .14

$352.304 .211,41$ 0,00

1.269.601.898,55

1.663.761.898,55 


\section{BAB III}

\section{PENUTUP}

\section{A. KESIMPULAN}

Tujuan dari analisis aspek keuangan studi kelayakan adalah untuk mengembangkan rencana investasi dengan membandingkan biaya dan pendapatan serta menghitung biaya dan manfaat yang diharapkan.

Ada dua jenis aset tetap: aset tetap berwujud dan aset tetap tidak berwujud. Rincian analisis biaya dari sumber pengeluaran untuk menghitung total biaya dana ditentukan oleh biaya pinjaman, biaya modal dan biaya laba ditahan.

\section{B. SARAN}

Harapan kami sebagai penulis, Semoga makalah ini dapat bermanfaat bagi pembaca, dan kami harapkan juga bahwa jangan hanya berfokus pada materi ini saja tetapi telusuri lebih dalam tentang Aspek keuangan melalui referensi-referensi lain yang dapat membatu meningkatkan pengetahuan kita tentang aspek keuangan kareana dalam penulisan makalah ini penulis menyadari bahwa materi tentang aspek keuangan masih sangat terbatas. 


\section{DAFTAR PUSTAKA}

Ejurnal.unisri.ac.id/index.php/widyawacana/article/viewFile/420/377

diakses pada 24 Sep. 2021. pukul 08.30 WIB.

Journal.uny.ac.id/index.php/cp/articleviewFile/383/pdf diakses pada 24 September 2021 pukul 08.33 WIB.

Kasmir dan Jakfar. Studi Kelayakan Bisnis. Edisi Kedua. Jakarta: Kencana Prenada Media Group, 2008.

Nasarudin, Indo Yama, “Analisis Kelayakan Ekonomi Dan Finansial Usaha Ikan Lele Asap Di Wilayah Pekanbaru”, Jurnal Etikonomi Volume 11 No.2, 2012.

Rangkuti, Freedy, "Business Plan, Teknik Membuat Perencanaan Bisnis dan Analisis Kasus”, PT. Gramedia Pustaka Utama, 2006.

Tanjung, Baharuddin Nur. Pedoman Penulisan Karya Ilmiah (Proposal, Skripsi, dan Tesis). Medan: Kencana Prenada Media Group, 2005.

Umar, Husein, “Studi Kelayakan Bisnis, Teknik Menganalisis

Kelayakan Usaha Secara Komperhensif”, PT. Gramedia Pustaka Utama,2005. 